\title{
LANDSLIDE SUSCEPTIBILITY MAPPING IN BERASTAGI DISTRICT KARO REGENCY BASED ON GEOGRAPHIC INFORMATION SYSTEMS
}

\author{
Desi Permata Sari ${ }^{1}$, Nahor Manahat Simanungkalit ${ }^{2}$, Nina Novira ${ }^{3}$ \\ ${ }^{1}$ Department of Geography Education, Faculty of Social Sciences, State University of Medan \\ Willem Iskandar Pasar V Street, Medan Estate, Percut Sei Tuan, Deli Serdang, 20371, \\ Indonesia
}

Email corresponding: nina.novira@gmail.com

\begin{tabular}{|c|c|c|}
\hline Submitted: & Accepted: & Published: \\
$04-09-2021$ & $10-09-2021$ & $30-09-2021$ \\
\hline
\end{tabular}

\begin{abstract}
This study aims to describe the spatial distribution of landslide prone areas in Berastagi District, Karo Regency with a Geographic Information System approach. Determination of the level of landslide susceptibility is obtained based on the method of scoring and weighting and overlaying of parameters including slope, rainfall, land use, soil type, rock type, and landform. The results showed that there were 4 levels of landslide susceptibility in Berastagi District, Karo Regency, namely low level of susceptibility 1,036.76 Ha (33.16\%), medium level of susceptibility $772.02 \mathrm{Ha}(24.69 \%)$, high level of susceptibility 1,055.53 Ha (33.76\%), and very high level of susceptibility $262.13 \mathrm{Ha}(8.38 \%)$. The low level of susceptibility is dominated by Guru Singa Village (10.83\%), Raya Village (8.66 \%), and Rumah Berastagi Village (3.72\%). The medium and high level of susceptibility were dominated by Sempajaya Village at $4.51 \%$ and $3.68 \%$. The very high level of susceptibility to landslides is dominated by Doulu Village, which is $17.40 \%$. Meanwhile, the other 5 (five) villages have varying levels of susceptibility to landslides. Thus, $33.16 \%$ of the Berastagi District area is still safe from landslides, while the remaining $66.83 \%$ is prone to landslides.
\end{abstract}

Key words: Mapping, Susceptibility, Disaster, Landslide, GIS

\section{INTRODUCTION}

According to Law Number 24 of 2007, a disaster is an event or series of events that threatens and disrupts people's lives and livelihoods caused by both natural and/or non-natural factors as well as human factors. resulting in human casualties, environmental damage, property losses, and psychological impacts. Based on this definition, according to the causal factors, disasters can be categorized into three types, namely natural disasters, non-natural disasters, and social disasters.

Landslides are included in the category of natural disasters caused by geological factors. Nohani et al. (2019) revealed that based on a report from the Center of Research on the Epidemiology of Disasters, landslides are the cause of $17 \%$ of all victims of natural disasters in the world. Landslides cause the evolution of landscapes and are considered the greatest threat in a large number of areas around the world. The tendency of damage caused by this disaster will increase in the future along with increasing urbanization, population growth, development of residential areas, deforestation, and climate change. According to Aversa et al. (2016), although they cause fewer casualties than other hazards, landslides are responsible for massive economic damage worldwide. Even smallscale landslides are a serious threat and greatly affect transportation corridors and disrupt human mobility and the distribution of goods.

Indonesian territory is not immune from the threat of landslides. Its position above the confluence of three of the world's major plates, namely the Eurasian plate, Pacific plate and Australian plate, has resulted in collisional activity between plates which then forms a subduction zone that stretches along the Indonesian archipelago. Starting from the west of the island of Sumatra, south of the island of Java to Bali and the Nusa Tenggara Islands, and north of the Maluku Islands to the north of Papua. This subduction zone gives rise to hills with slopes varying from steep to gentle. Such conditions cause Indonesia to have a fairly high threat of natural disasters from landslides (BNPB, 2016).

According to Damanik and Restu (2012), North Sumatra Province is one of the areas on the island of Sumatra that is affected by the 
subduction zone with the main threat of landslides. There are 15 districts/cities prone to landslides out of 78 districts/cities in North Sumatra Province. The area includes Central Tapanuli Regency, South Tapanuli Regency, Mandailing Natal Regency, Padang Sidempuan City, Sibolga City, Dairi Regency, Humbang Hasundutan Regency, Nias Regency, South Nias Regency, Karo Regency, Dairi Regency, West Pha-phak Regency, Samosir Regency, Toba Samosir Regency, and Simalungun Regency.

Karo Regency is one of the landslide-prone areas in North Sumatra Province because most of its territory is a highland located in the Bukit Barisan Mountains range with hilly and undulating topography. The area has cold air with air temperatures ranging from $17.4^{\circ} \mathrm{C}$ to $23.6^{\circ} \mathrm{C}$ and an average air humidity of $88.39 \%$ which produces a fairly high average rainfall of around 1,000 - 4,000 mm/year (Profile Karo Regency 2015-2019).

Based on data from the Center for Volcanology and Geological Hazard Mitigation (2017), Karo Regency has several potential areas for landslides. The potential areas for landslides in Karo Regency can be seen in Table 1. There are 107 villages/kelurahan that were recorded as experiencing landslides in the three years of enumeration. The top five sub-districts with villages that experienced the most landslides were Barusjahe Subdistrict with 16 villages, Juhar Subdistrict with 15 villages, Munte Subdistrict with 14 villages, Merdeka Subdistrict and Tigapanah Subdistrict with 10 villages, and Berastagi District with 7 villages.

Table 1 Potential Land Movement Areas in Karo Regency, North Sumatra Province

\begin{tabular}{lll}
\hline No & Subdistrict & $\begin{array}{l}\text { Potential for Land } \\
\text { Movements }\end{array}$ \\
\hline 1. & Barusjahe & Medium - High \\
2. & Berastagi & Medium - High \\
3. & Dolarakyat & Middle - High \\
4. & Juhar & Medium - High \\
5. & Kabanjahe & Medium \\
6. & Kutabuluh & Medium \\
7. & Laubaleng & Medium - High \\
8. & Mardingding & Medium \\
9. & Merdeka & Medium - High \\
10. & Brand & Medium - High \\
11. & Munte & Medium \\
12. & Namanteran & Medium - High \\
13. & Umbrella & Medium - High \\
14. & Simpangempat & Intermediate \\
15. & Tigabinanga & Medium - High \\
16. & Tiganderket & Medium - High \\
17. & Tigapanah & Medium \\
\hline & Source: PVMBG, 2017. Accessed on December 20, 2019
\end{tabular}

Berastagi District is one of the sub-districts in Karo Regency that has medium to high landslide potential. Berastagi District occupies the top 5 (five) rankings for landslides, covering 7 out of 10 villages/kelurahan. The topography of Berastagi District is flat to choppy (65\%), wavy to hilly $(22 \%)$, hilly to mountainous (13\%). The air temperature level is $19^{\circ} \mathrm{C}$ to $26^{\circ} \mathrm{C}$ with air humidity ranging from $79 \%$ and an average rainfall of 2,100 to $3,200 \mathrm{~mm}$ per year (BPS Berastagi District, 2019).

Berastagi is the second largest city after Kabanjahe City, but the sub-district with the smallest area is in Karo Regency, which is $3,126.44 \mathrm{Ha}$. Berastagi is also the sub-district with the second highest population density after Kabanjahe, reaching 1,575.41 people $/ \mathrm{km}^{2}$. The number of human activities drives the high level of land use. Areas with rice fields and cultivation make the soil soft and saturated with water because plant roots are not strong enough to bind soil grains so landslides are easy to occur. The presence of additional loads in the form of residential buildings and transportation infrastructure on the slopes will increase the driving force for landslides (Anonymous, 2006).

Based on the description of physical conditions, human activities, and landslides that have occurred in Berastagi District, it is necessary to identify and map landslide-prone areas that are able to provide an overview of the existing condition of the area based on the driving factors for landslides. Landslide hazards can be identified quickly through the Geographic Information System through mapping the spatial distribution of landslideprone areas using the method of overlaying the parameters of landslide susceptibility. Mapping activities are an initial mitigation effort to identify disaster-prone areas in order to minimize the risks caused by landslides.

\section{METHODS}

This research is located in Berastagi District, Karo Regency. The population in this study includes all land that is included in the administrative area of Berastagi District, Karo Regency. The sampling technique used is purposive sampling. The samples in this study were the locations of landslides in Berastagi District, Karo Regency.

The equipment used in this research include: hardware (laptops and printers), software (ArcGIS 10.1 and Microsoft Office 2010), GPS, Abney Level, meters, digital cameras, and stationery. The materials needed in this study include: Quickbird image of Berastagi District, Digital Map of the Administrative Area of Berastagi District, Digital Map of Slope of Berastagi District, 
Digital Map of Rainfall in Berastagi District, Digital Map of Land Use in Berastagi District, Digital Map of Soil Types in Berastagi District, Digital Map of Geology of Berastagi District, and Digital Map of Landforms in Berastagi District.

The data collection technique in this research is a documentary study to obtain secondary data and observation to collect primary data and determine the level of accuracy of the mapping using the following formula.

Tingkat kebenaran interpretasi $=\frac{\sum \text { Titik benar }}{\sum \text { Titik survei }} \times 100 \%$

The data analysis technique used in this study is the method of scoring and weighting the parameters of landslide susceptibility (Tables2-7), overlay, and presented in the form of descriptive analysis.

Table 2. Slope Classification (\%)

\begin{tabular}{ccc}
\hline Parameter & Weight & Score \\
\hline$<8$ & $30 \%$ & 1 \\
$8-15$ & & 2 \\
$15-25$ & & 3 \\
$25-45$ & 4 \\
$>45$ & 5 \\
\hline \multicolumn{3}{r}{ Source: Minister of Agriculture (1980) }
\end{tabular}

Table 3. Classification of Rainfall (mm/year)

\begin{tabular}{ccc}
\hline Parameter & Weight & Score \\
\hline$(0-1000)$ & $20 \%$ & 1 \\
$1000-1500$ & & 2 \\
$1500-2000$ & & 3 \\
$2000-2500$ & & 4 \\
$>2500$ & & 5 \\
\hline
\end{tabular}

Table 4. Land Use Classification

\begin{tabular}{ccc}
\hline Parameter & Weight & Score \\
\hline Ponds, reservoirs, & $15 \%$ & 1 \\
waters & & 2 \\
City / settlement & & 3 \\
Forests and & & \\
plantations & & 4 \\
Shrubs & 5 \\
Upland, rice fields & & \\
\hline
\end{tabular}

Source: Quickbird image (2020)

Table 5. Soil Type Classification

\begin{tabular}{ccc}
\hline Parameter & Weight & Score \\
\hline Histosol & $15 \%$ & 1 \\
Entisol & & 2 \\
Inceptisol & & 3 \\
Moltisol & & 4 \\
Alfisol & & 5 \\
Ultisol & & 6 \\
\hline
\end{tabular}

\begin{tabular}{ccc}
\hline Parameter & Weight & Score \\
\hline Oxisol & & 7 \\
\hline & Source: Nurwihastuti, et al (2016)
\end{tabular}

Table 6. Classification of Rock Type

\begin{tabular}{ccc}
\hline Parameter & Weight & Score \\
\hline Alluvial rock & $10 \%$ & 1 \\
$\begin{array}{c}\text { Sedimentary } \\
\text { rock }\end{array}$ & & 2 \\
Volcanic rock & & 3 \\
\hline & & Source: BNPB (2016)
\end{tabular}

Table 7. Landform classification

\begin{tabular}{ccc}
\hline Parameter & $\begin{array}{c}\text { Weight } \\
\text { ing }\end{array}$ & Score \\
\hline Alluvial plain & $10 \%$ & 1 \\
Highlands & & 2 \\
Karst hills & & 3 \\
Volcanoes & 4 \\
Remaining hills & 5 \\
Denudational hill slopes & 6 \\
Denudational hills & & \\
Slopes contemplation & & \\
denudasional & Mountains denudasional & 10 \\
Slope mountains structural & \\
denudasional & 11 \\
Structural Mountains & \\
denudasional & & \\
\hline Source: Nurwihastuti, et al (2016)
\end{tabular}

These tables are a classification of parameters landslide susceptibility that has been given a score and weighting. The next action is to overlay the thematic maps (figures 2 - 7). The total score of the landslide susceptibility parameter is calculated based on the following formula.

TOTAL SCORE $=0.3 S K L+0.2 S C H+$

$0.15 S P L+0.15 S J T+0.1 S J B+0.1 S B L$

Description:

SKL = Score Slopes

$\mathrm{SCH}=$ Score Rainfall

SPL = Score Land Use

SJT = Score Soil Type

SJB = Score Type rocks

SBL = Score landforms

Final classify of landslides susceptibility grouped into four (4) class intervals, namely low, medium, high, and very high with the following formula.

$$
\text { Class }=\frac{\text { Highest score }- \text { Lowest score }}{\text { Number of classes }}
$$




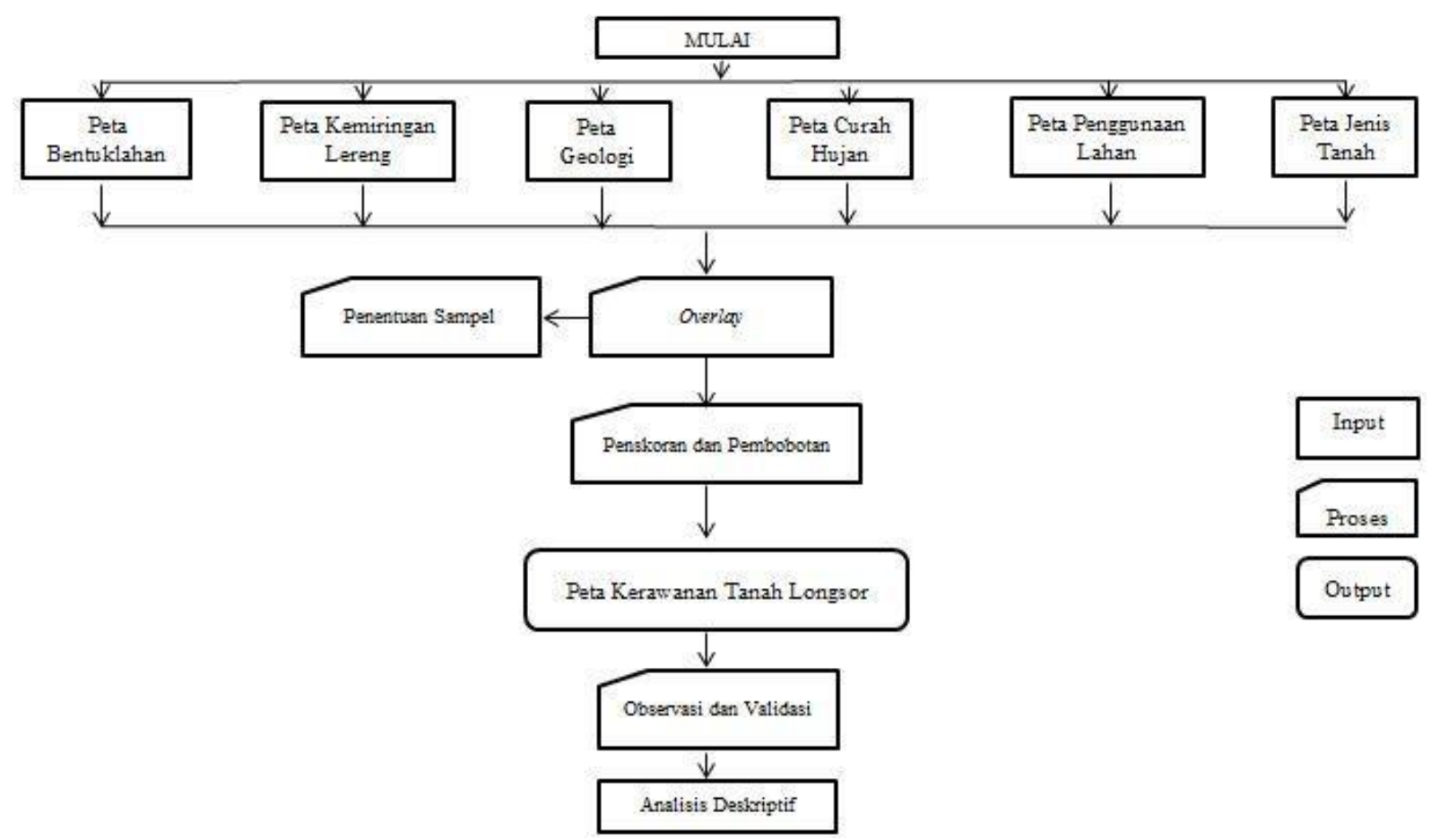

Figure 1. Research Flowchart

\section{RESULTS AND DISCUSSION}

\section{Area Description}

Astronomically the area of Berastagi District is located between $03^{\circ} 9^{\prime}-03^{\circ} 11^{\prime}$ North Latitude and $98^{\circ} 30^{\prime}-98^{\circ} 31^{\prime}$ 'Longitude East. Geographically, the area of Berastagi District is bordered by the following areas, in the north with Deli Serdang Regency; to the south with Kabanjahe District; in the west with Simpang Empat and Merdeka subdistricts; in the east with Tigapanah District and Dolat Rayat District.

Berastagi District consists of 10 (ten) villages, namely Guru Singa, Raya, Rumah Berastagi, Sempajaya, Doulu, and Lau Gumba, namely Gundaling I, Gundaling II, Tambak Lau Mulgap I, Tambak Lau Mulgap II, with a total area of $3,126.44 \mathrm{Ha}$.

\section{Slope Parameters}

Most of the Berastagi District is located on a stretch of plateau with an elevation ranging from 1,265 - 1,417 meters above sea level. The topography of Berastagi District varies from flat - choppy $( \pm 65 \%)$, choppy - hilly $( \pm 22 \%)$, and hilly - mountainous $( \pm 13 \%)$. By using the Digital Elevation Model (DEM) classification, Berastagi District can be classified into 5 (five) slope classifications which are described in Table 8.

Table 8. Area and Distribution of Land Slope in Berastagi District

\begin{tabular}{|c|c|c|c|c|c|c|}
\hline \multirow[t]{2}{*}{ No } & \multirow[t]{2}{*}{ Village } & \multicolumn{5}{|c|}{ Area Slope $(\mathrm{Ha})$} \\
\hline & & $\begin{array}{l}\text { Flat } \\
(<8 \%)\end{array}$ & $\begin{array}{l}\text { Ramps } \\
(8-15 \%)\end{array}$ & $\begin{array}{c}\text { A bit steep } \\
(15-25 \%)\end{array}$ & $\begin{array}{c}\text { Steep } \\
(25-45 \%)\end{array}$ & $\begin{array}{c}\text { Very steep } \\
(>45 \%)\end{array}$ \\
\hline 1 & Guru Singa & 339.83 & 66.34 & 38.39 & 43.38 & 64,35 \\
\hline 2 & Raya & 271.73 & 52.50 & 32.29 & 32.69 & 59.82 \\
\hline 3 & $\begin{array}{l}\text { Rumah } \\
\text { Berastagi }\end{array}$ & 111.36 & 28.95 & 21.73 & 20.02 & 25.33 \\
\hline 4 & $\begin{array}{l}\text { Tambak Lau } \\
\text { Mulgap II }\end{array}$ & 67.24 & 25.92 & 19,07 & 23.86 & 29.36 \\
\hline 5 & Gundaling II & 56.09 & 14.05 & 7.84 & 14.31 & 15.90 \\
\hline 6 & Gundaling I & 46.39 & 44.49 & 31.75 & 28.96 & 19.81 \\
\hline 7 & $\begin{array}{l}\text { Tambak Lau } \\
\text { Mulgap I }\end{array}$ & 16,46 & 12.90 & 14.11 & 15.87 & 14.29 \\
\hline 8 & Sempajaya & $\begin{array}{l}66.58271 .7 \\
4\end{array}$ & 68.85 & & 37.53 & 113.04 \\
\hline 9 & Doulu & $\begin{array}{l}162.81 \\
218.09\end{array}$ & 90.22 & & & 153.63 \\
\hline
\end{tabular}




\begin{tabular}{|c|c|c|c|c|c|c|}
\hline \multirow[t]{2}{*}{ No } & \multirow[t]{2}{*}{ Village } & \multicolumn{5}{|c|}{ Area Slope $(\mathrm{Ha})$} \\
\hline & & $\begin{array}{l}\text { Flat } \\
(<8 \%)\end{array}$ & $\begin{array}{l}\text { Ramps } \\
(8-15 \%)\end{array}$ & $\begin{array}{c}\text { A bit steep } \\
(15-25 \%)\end{array}$ & $\begin{array}{c}\text { Steep } \\
(25-45 \%)\end{array}$ & $\begin{array}{c}\text { Very steep } \\
(>45 \%)\end{array}$ \\
\hline $\begin{array}{l}10 \\
\text { Total }\end{array}$ & Lau Gumba & $\begin{array}{l}323.72 \\
21.06 \\
1,196.88\end{array}$ & $\begin{array}{l}28.19 \\
432.48\end{array}$ & $\begin{array}{l}27.91 \\
422.64\end{array}$ & $\begin{array}{l}16.00 \\
479.80\end{array}$ & $\begin{array}{l}4.48 \\
594.64\end{array}$ \\
\hline
\end{tabular}

\section{Rainfall Parameters}

According to Junghuhn climate classification theory, the region subdistrict Berastagi is included in the temperate climate zone (700 - 1,500 meters above sea level) because it is located at an altitude between 1,265 - 1,417 meters above sea level. Meanwhile, according to the SchmidtFerguson theory, based on the calculation of the comparison of the number of wet months with dry months, the Berastagi sub-district is included in the tropical climate type A (very wet) with air temperatures ranging from 19 to $26{ }^{\circ} \mathrm{C}$. The calculation of this rainfall distribution is based on data obtained from 2 (two) rainfall stations that cover the research area, namely Kuta Gadung and Tongkoh (Berastagi) Stations.

The intensity and distribution of rainfall in Berastagi District is influenced by location factors in mountainous areas. Based on data obtained from observation stations, rainfall in the Berastagi sub-district is medium to very high, namely between 1500 to more than $2500 \mathrm{~mm} /$ year. Rain factors such as rain intensity, amount of rainfall, and distribution of rainfall can determine the location of the opportunity for landslides to occur and how big the danger of landslides is.

Based on the results of the classification of annual rainfall parameters, the intensity of very high rainfall $(>2500 \mathrm{~mm} /$ year) has the highest distribution area, with an area of $1,436.27 \mathrm{Ha}$ or $45.93 \%$ of the research site area. The second order is followed by the intensity of medium rainfall $(1500-2000$ $\mathrm{mm} /$ year) with a distribution area of $1,151.46$ $\mathrm{Ha}$ or $36.82 \%$ of the research site area. Meanwhile, the high rainfall intensity (2000 $2500 \mathrm{~mm} /$ year) has the narrowest distribution area, which is 538.71 or $17.23 \%$ of the research location area.

Table 9. Classification of Annual Rainfall in Berastagi District

\begin{tabular}{cccr}
\hline No. & Rainfall & Parameter & Area (Ha) \\
\hline $\mathbf{1}$ & $1500-2000 \mathrm{~mm} /$ year & Medium & $1,151.46$ \\
$\mathbf{2}$ & $2000-2500 \mathrm{~mm} /$ year & High & 538.71 \\
$\mathbf{3}$ & $>2500 \mathrm{~mm} /$ year & Very High & $1,436.27$ \\
Total & & & $3,126,44$
\end{tabular}

Source:Research Data Processing Results (2020)

\section{Land Use Parameters}

Aspects of land use in an area are closely related to economic conditions and the type of community living in the area. Land cover types have different contributions in determining the area's vulnerability. Things that contribute to the formation of landslideprone areas from land use, for example the nature and conditions of land cover, such as buildings or plants, types and characteristics of plants, as well as the extent of closure and location of closure. The area and distribution of land use in Berastagi District can be seen in Table 10 and Figure 4.

The most extensive type of land use found in Berastagi District is land use for dry fields/fields with an area of 1,428.73 $\mathrm{Ha}$ or
$45.69 \%$ of the total area research sites. This type of land use is mostly found in Guru Singa Village, namely 425.49 (Ha) while the narrowest is in Tambak Lau Mulgap I village, which is $9.59 \mathrm{Ha}$.

Furthermore, the most extensive use of forest land is in Doulu Village, which is 755.80 ha, while in Raya Village, Berastagi House, Lau Mulgap II, Gundaling II, Gundaling I, Lau Mulgap I, Sempajaya, Doulu, Lau Gumba, there is no forest land use. The total area of land in the forest sector is $809.75 \mathrm{Ha}$. There are many forest vegetation in the research area, including Pine, Meranti, Mahogany, and so on.

In the land use for residential areas, the most extensive is in Gundaling I Village, which 


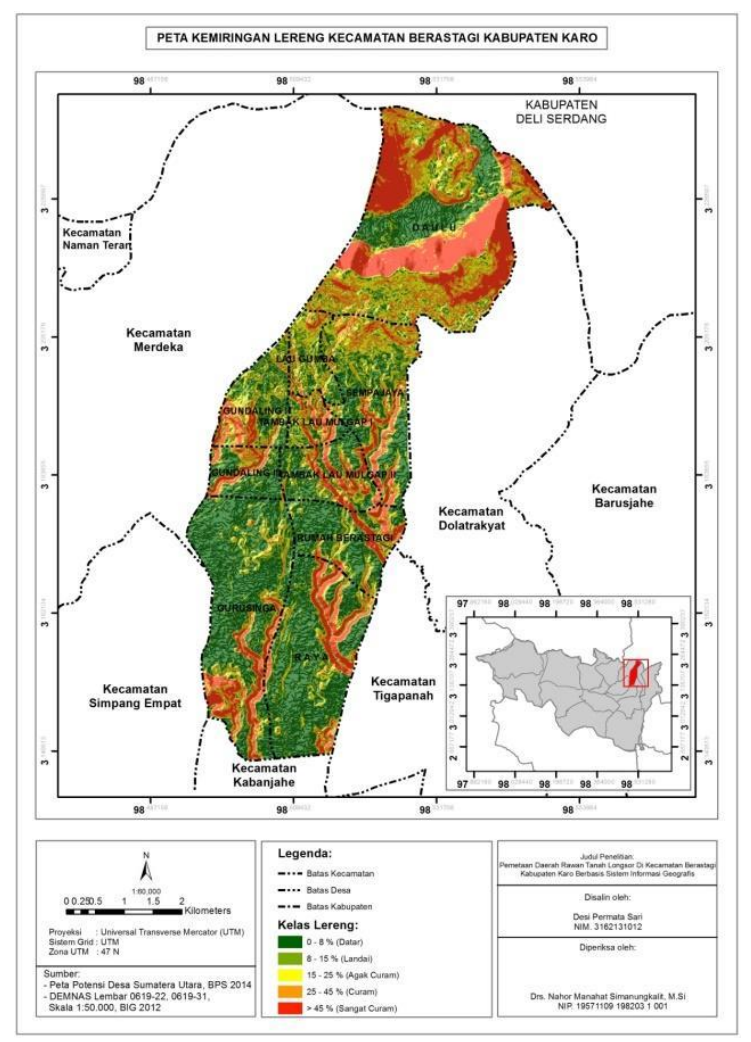

Figure 2. Slope Map of Berastagi Subdistrict, Karo Regency

is $59.30 \mathrm{Ha}$. Meanwhile, the area with the narrowest settlement is in Doulu Village, which is only 7.89 ha. The total area of land use for settlements in Berastagi District is $272.98 \mathrm{Ha}$.

The most extensive use of land for rice fields is in Doulu Village, which is $131.36 \mathrm{Ha}$. While in Gundaling II and Gundaling I villages

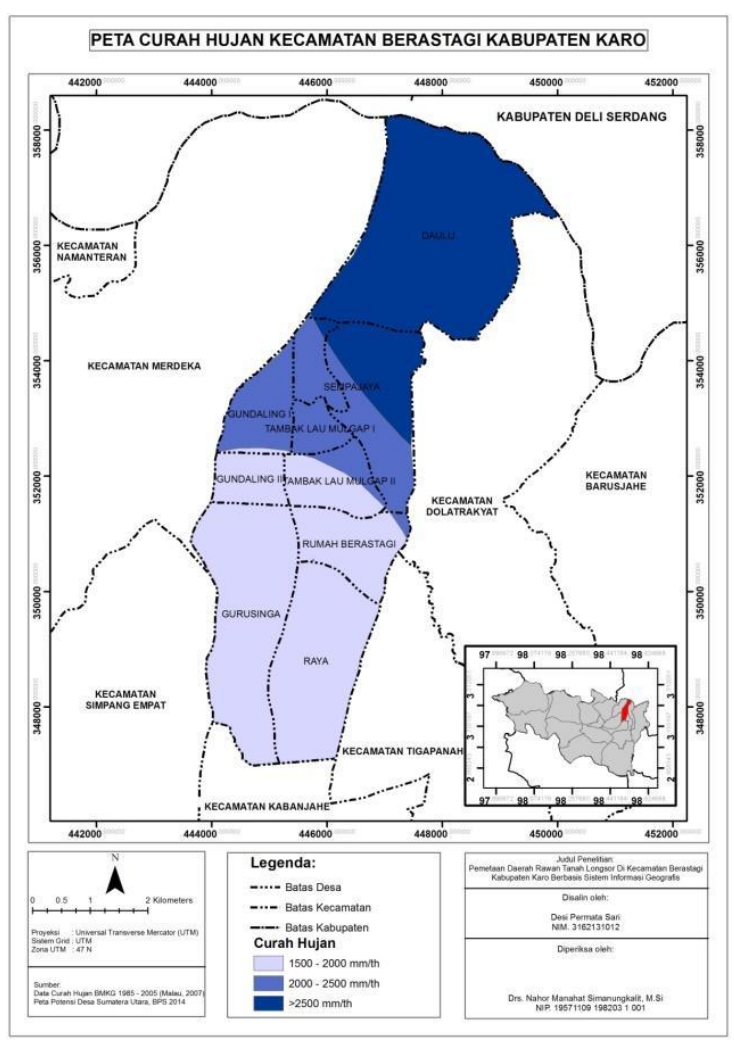

Figure 3. Annual Rainfall Map of Berastagi Subdistrict

there is no use of paddy fields. The total area of paddy field use is $259.01 \mathrm{Ha}$.

The most extensive shrubs are in Guru Singa Village, which is $75.10 \mathrm{Ha}$. While the narrowest use of bushland is in Lau Gumba Village. The total area of shrubs is 355.95 ha. The shrubs are overgrown with types of weeds such as reeds, shrubs, ferns, and others.

Table 10. Area and Distribution of Land Use in Berastagi Subdistrict

\begin{tabular}{|c|c|c|c|c|c|c|c|}
\hline \multirow[t]{2}{*}{ No } & \multirow{2}{*}{\multicolumn{2}{|c|}{ Village }} & \multicolumn{5}{|c|}{ Area Type of Land Use (Ha) } \\
\hline & & & $\begin{array}{l}\text { Upland/Fi } \\
\text { eld }\end{array}$ & Forest & Settlement & Rice & Bushes \\
\hline 1 & Guru Singa & & 425.49 & 31.26 & 20.11 & 0.43 & 75.10 \\
\hline 2 & Raya & & 311.29 & 0 & 38.22 & 62.80 & 36.80 \\
\hline 3 & $\begin{array}{l}\text { Rumah } \\
\text { Berastagi }\end{array}$ & & 128.64 & 0 & 14.71 & 17.73 & 46.62 \\
\hline 4 & $\begin{array}{l}\text { Tambak } \\
\text { Mulgap II }\end{array}$ & Lau & 85.95 & 0 & 25.69 & 24.95 & 28.86 \\
\hline 5 & Gundaling II & & 68.30 & 0 & 14.44 & 0 & 25.46 \\
\hline 6 & Gundaling I & & 59.30 & 0 & 84.39 & 0 & 29.1 \\
\hline 7 & $\begin{array}{l}\text { Tambak } \\
\text { Mulgap I }\end{array}$ & Lau & 28.88 & 0 & 22.32 & 12.84 & 9.59 \\
\hline 8 & Sempajaya & & 210.72 & 1625 & 44.52 & 8.83 & 73.14 \\
\hline 9 & Doulu & & 43.31 & 755.80 & 7.89 & 131.36 & 8.30 \\
\hline 10 & Lau Gumba & & 61.00 & 6.43 & 25.70 & 0.03 & 4.56 \\
\hline Total & & & $1,428.73$ & 809,75 & 272.98 & 259.01 & 355.95 \\
\hline
\end{tabular}

\section{Soil Type Parameters Soil}

Types at the research site are classified based on the Soil Map of the Research and Development Center for Agricultural SDL consisting of Inceptisol and Ultisol soils. The spatial distribution of soil types at the study site is shown in Table 11 and Figure 5. Inceptisol soil types have the widest 
distribution of $3,113.39 \mathrm{Ha}$. Inceptisol soil belongs to the category of alluvial soil and has a dusty loam texture. Meanwhile, the Ultisol soil type is only found in a small part in Doulu Village with an area of $13.05 \mathrm{Ha}$. Ultisol soil type belongs to the red yellow podzolic soil category. Its characteristics include deep soil cross-section, acid soil reaction so that it is easily washed off by rainfall, and clay accumulation in the lower horizon. This causes reduced water absorption capacity and increased surface runoff and soil erosion.

\section{Parameters of Rock}

Types Volcanic rock types are the most dominant rock types in this region (95.27\%).

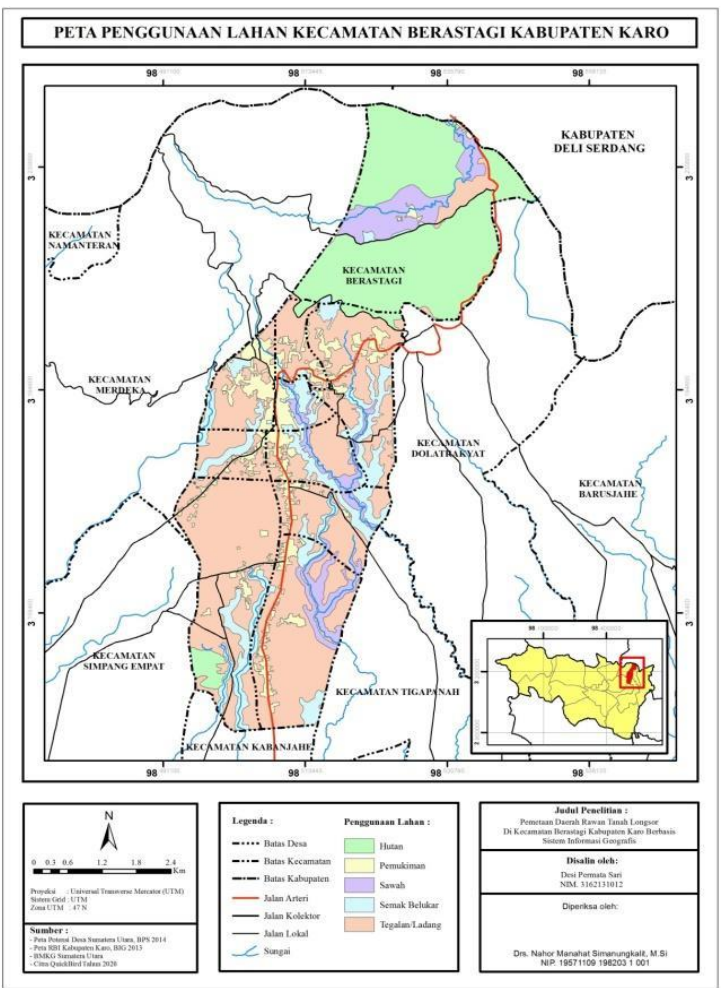

Figure 4. Land Use Map of Berastagi Subdistrict, Karo Regency
The type of rock QTvk which is part of the Takur-takur formation with pyroclastic material and is most abundant in Gundaling I village is $88.70 \mathrm{Ha}$. The total area of this rock type is $138.04 \mathrm{Ha}$ or $4.41 \%$ of the total area of the study area. In other volcanic rock types, namely Qvba, it is part of the Sibayak unit formation with andesite lava material. This type of rock is only found in Doulu village, which is 300.15 ha. Meanwhile, the rock type Qvbs (Unit Singkut) consists of tuff rock material spread throughout the villages in Berastagi District with a total area of $2,540.66 \mathrm{Ha}$ or $81.26 \%$ of the total area of the study area.

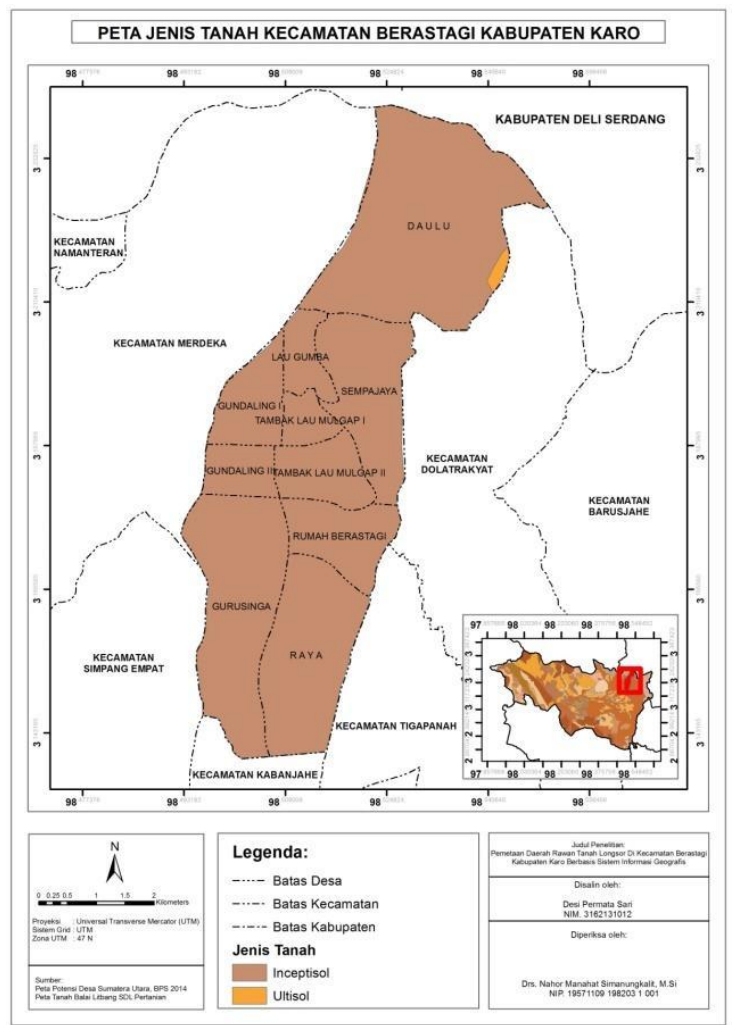

Figure 5. Map of Soil Types in Berastagi Subdistrict, Karo Regency

Table 11. Area and Distribution of Soil Types in Sub-district Berastagi

\begin{tabular}{llrr}
\hline No. & Village & \multicolumn{3}{c}{ Area Soil Type (Ha) } \\
\cline { 3 - 4 } 1. & Guru Singa & Inceptisol & Ultisol \\
2. & Raya & 452.40 & 0 \\
3. & Rumah Berastagi & 207.72 & 0 \\
4. & Pond Lau Mulgap II & 165.47 & 0 \\
5. & Gundaling II & 108,22 & 0 \\
6. & Gundaling I & 171.87 & 0 \\
7. & Pond Lau Mulgap I & 73.65 & 0 \\
8. & Sempajaya & 353.50 & 0 \\
9. & Doulu & 933.62 & 0 \\
10. & Lau Gumba & 97.75 & 13.05 \\
Total & $3,113.39$ & 13,05 \\
\hline
\end{tabular}

The next rock type, namely Alluvial, has a

Source: Research Data Processing Results (2020)

total area of $147.59 \mathrm{Ha}$ or $4.73 \%$ of the total 
area of the study area. The rock type $\mathrm{Qh}$ is a young alluvium rock with loose sedimentary material located mostly in Doulu village, which is $81.46 \mathrm{Ha}$. While in the villages of Guru Singa, Raya, Gundaling II, Gundaling I, Tambak Lau Mulgap I and Lau Gumba there is no distribution of this rock type.

\section{Parameters of Landforms}

The research area only has 1 (one) type of

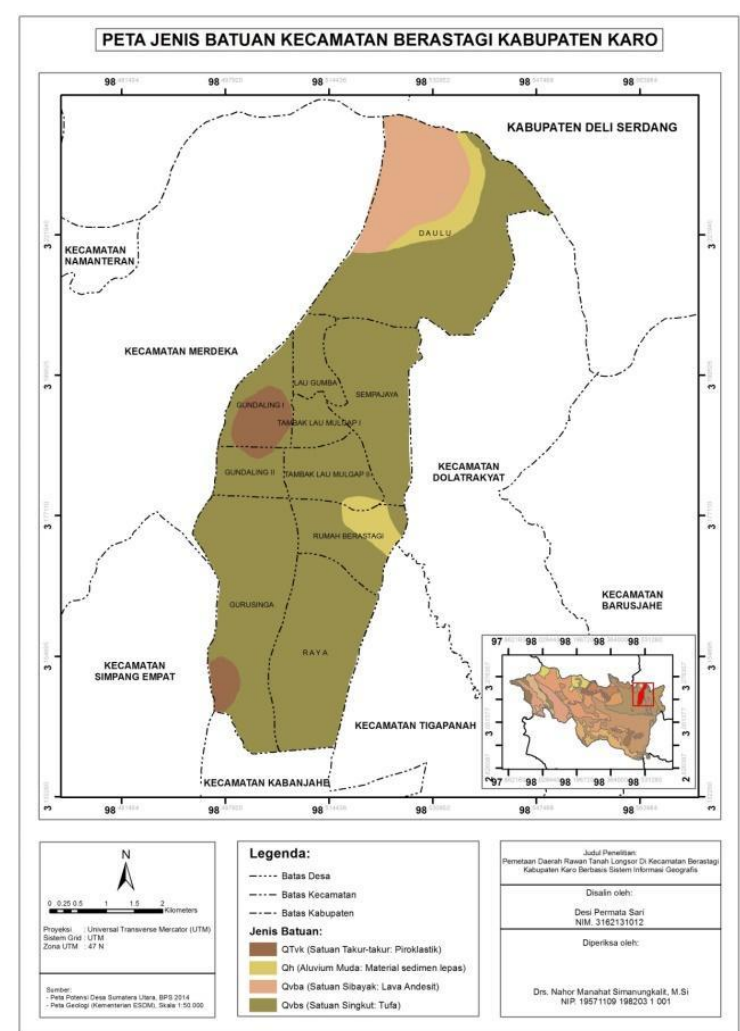

Figure 6. Map of Rock Types, Berastagi District, Karo Regency. landform, namely volcanic fallout deposits. Berastagi area is part of the accumulation of volcanic material. The area of the volcanic fall sediment landform in Berastagi District is adjusted to the area of the research area itself, because the entire area of Berastagi District with an area of $3,126.44 \mathrm{Ha}$ is included in the same landform.

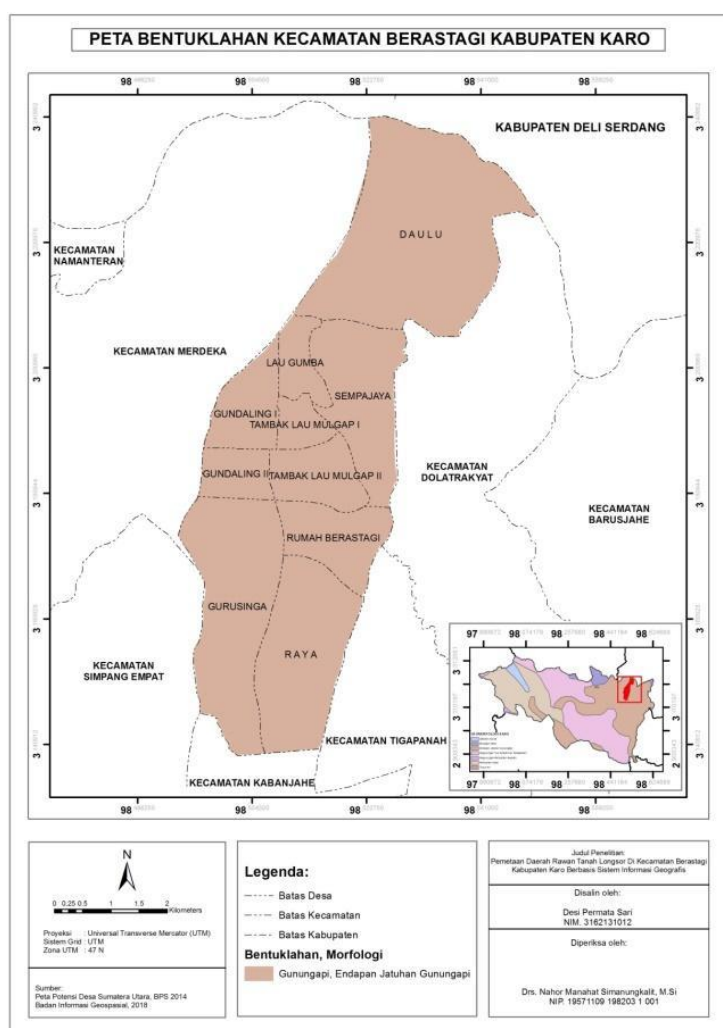

Figure 7. Map of landforms in Berastagi Subdistrict, Karo Regency

Table 12. Area and Distribution of Rock Types in Berastagi Sub-district

\begin{tabular}{ll}
\hline No. & Village \\
1. & Lion Master \\
2. & Raya \\
3. & Berastagi House \\
4. & Tambak Lau Mulgap II \\
5. & Gundaling II \\
6. & Gundaling I \\
7. & Mulgap Lau pond I \\
8. & Sempajaya \\
9. & Doulu \\
10. & Lau Gumba \\
Total &
\end{tabular}

\begin{tabular}{rrrr}
\multicolumn{5}{c}{ Area of Rock Type (Ha) } \\
\hline QTvk & Qh & \multicolumn{1}{c}{ Qvba } & \multicolumn{1}{l}{ Qvbs } \\
40.60 & 0 & 0 & 511.81 \\
0 & 0 & 0 & 449.13 \\
0 & 53.02 & 0 & 154.69 \\
0 & 12.61 & 0 & 152.86 \\
8.73 & 0 & 0 & 99.49 \\
88.70 & 0 & 0 & 83.18 \\
0 & 0 & 0 & 73.65 \\
0 & 0.49 & 0 & 353.01 \\
0 & 81.46 & 300.15 & 565.05 \\
0 & 0 & 0 & 97.75 \\
138.04 & 147.59 & 300.15 & $2.540,66$ \\
\hline \multicolumn{4}{c}{ Source: Research Data (2020) }
\end{tabular}

\section{Landslide Vulnerability}

Based on the results of secondary data analysis, research uses a scoring and weighting method based on the Geographic Information System on 6 (six) landslide susceptibility parameters, namely Slope, Rainfall, Land Use, Soil Type, Rock Type, and Landform, obtained 4 (four) levels (classes) of landslide susceptibility found in Berastagi District, Karo Regency. Based on the data 
shown in table 13, the high level of landslide susceptibility has the widest distribution, which is $1,055.53 \mathrm{Ha}$ or $33.76 \%$ of the research area. This is followed by a low grade landslide susceptibility level, which is $1,036.76 \mathrm{Ha}$ or $33.16 \%$ of the total area of the research area. Furthermore, the moderate level of vulnerability to landslides has an area of $772.02 \mathrm{Ha}$ or $24.69 \%$ of the research area. Meanwhile, the very high level of vulnerability to landslides has a distribution with the least area, which is $262.13 \mathrm{Ha}$ or $8.38 \%$ of the total area of the research area.

Table 13. Landslide Vulnerability Level in Berastagi Sub-district, Karo Regency

\begin{tabular}{lcrrr}
\hline No. & Vulnerability Level & Interval & Area (Ha) & Percentage (\%) \\
\hline 1. & Low & $0.30-1.28$ & 1.036 .76 & 33.16 \\
2. & Medium & $1.29-2.25$ & 772.02 & 24,70 \\
3. & High & $2.25-3.23$ & $1,055.53$ & 33.76 \\
4. & Very High & $3.24-4.20$ & 262.13 & 8.38 \\
Total & & & $3,126.44$ & 100 \\
\hline
\end{tabular}

Source: Research Data Processing Results (2020)

\section{Spatial Distribution of Land Prone Areas Landslide}

Based on the data presented in Table 14, it can be described the distribution of landslide-prone areas and the area of vulnerability classes based on each administrative area of 10 villages in Berastagi District as follows.

a. Low-level landslide susceptibility

Distribution of areas with low-level landslide susceptibility in Berastagi District has a total area of $1,036.75 \mathrm{Ha}$ or $33.72 \%$ of the total area of the study area. Areas with a low level of vulnerability to landslides are mostly located in the western part of Berastagi District, especially in Gurusinga Village with an area of $338.60 \mathrm{Ha}$. Meanwhile, the village with the narrowest distribution of areas with a low level of vulnerability to landslides is Lau Gumba Village with an area of $9.66 \mathrm{Ha}$.

Table 14. Spatial Distribution of Landslide Prone Areas Based on Administrative Areas of Berastagi Subdistrict

\begin{tabular}{|c|c|c|c|c|c|c|c|c|c|c|}
\hline \multirow[t]{3}{*}{ No } & \multirow{2}{*}{\multicolumn{2}{|c|}{ Village }} & \multicolumn{8}{|c|}{ Area of Class Vulnerability } \\
\hline & & & \multicolumn{2}{|c|}{ Low } & \multicolumn{2}{|c|}{ Medium } & \multicolumn{2}{|c|}{ High } & \multicolumn{2}{|c|}{ Very High } \\
\hline & & & $\mathrm{Ha}$ & $\%$ & $\mathrm{Ha}$ & $\%$ & $\mathrm{Ha}$ & $\%$ & $\mathrm{Ha}$ & $\%$ \\
\hline 1. & \multicolumn{2}{|l|}{ Guru Singa } & 338,60 & 10,83 & 69,99 & 2,23 & 98,41 & 3,14 & 45,40 & 1,54 \\
\hline \multirow[t]{2}{*}{2.} & \multicolumn{2}{|l|}{ Raya } & 270,95 & 8,66 & 54,56 & 1,74 & 63,79 & 2,04 & 59,81 & 1,91 \\
\hline & \multicolumn{2}{|l|}{$\begin{array}{l}\text { Rumah } \\
\text { Berastagi }\end{array}$} & 116,53 & 3,72 & 32,38 & 1,03 & 51,00 & 1,63 & 7,81 & 0,24 \\
\hline 4. & $\begin{array}{l}\text { Tambak } \\
\text { Mulgap II }\end{array}$ & Lau & 68,22 & 2,18 & 29,38 & 0,93 & 41,69 & 1,33 & 26,18 & 0,83 \\
\hline 5. & Gundaling II & & 54,85 & 1,75 & 15,82 & 0,50 & 21,62 & 0,69 & 15,89 & 0,50 \\
\hline 6. & Gundaling I & & 40,34 & 1,29 & 60,73 & 1,94 & 51,27 & 1,63 & 19,54 & 0,62 \\
\hline 7. & $\begin{array}{l}\text { Tambak } \\
\text { Mulgap I }\end{array}$ & Lau & 14,79 & 0,47 & 20,15 & 0,64 & 24,54 & 0,78 & 14,15 & 0,45 \\
\hline 8. & Sempajaya & & 43,94 & 1,40 & 141,17 & 4,51 & 115,10 & 3,68 & 14,79 & 0,47 \\
\hline 9. & Doulu & & 78,82 & 2,52 & 306,42 & 9,80 & 544,03 & 17,40 & 17,39 & 0,55 \\
\hline 10. & Lau Gumba & & 9,66 & 0,30 & 41,40 & 1,32 & 44,03 & 1,40 & 2,64 & 0,08 \\
\hline \multicolumn{3}{|c|}{ Total (Ha) } & $1.036,75$ & 33,16 & 772,02 & 24,70 & $1.055,53$ & 33,76 & 262,14 & 8,38 \\
\hline
\end{tabular}

Source: Research Data Processing Results (2020)

b. Medium-level landslide susceptibility Distribution of areas with a high level of vulnerability Landslide fields in Berastagi District have a total area of $772.02 \mathrm{Ha}$ or $25.11 \%$ of the total area of the study area. Areas with a medium level of vulnerability to landslides are mostly located in the northern part of Berastagi
District, especially in Doulu Village with an area of $306.42 \mathrm{Ha}$. Meanwhile, the village with the narrowest distribution area with a moderate level of vulnerability to landslides is Gundaling II Village with an area of $15.82 \mathrm{Ha}$.

c. High level of landslide susceptibility 
Distribution of areas with a high level of landslide susceptibility in the District of Berastagi has a total area of $1,055.53$ ha or $34.33 \%$ of the total area of the study area. Areas with a high level of vulnerability to landslides are mostly located in the northern part of Berastagi District, especially in Doulu Village with an area of $329.77 \mathrm{Ha}$. Meanwhile, the village with the narrowest distribution area with a high level of vulnerability to landslides is Lau Gumba Village with an area of $14.62 \mathrm{Ha}$.

d. Very high landslide susceptibility Distribution of areas with a very high level of vulnerability to landslides in the Berastagi District has a total area of $262.13 \mathrm{Ha}$ or $6.81 \%$ of the total area of the study area. Areas with a high level of vulnerability to landslides are mostly located in the eastern part of Berastagi District, especially in Raya Village with an area of 59.81 hectares. Meanwhile, the village with the narrowest distribution area with a very high level of vulnerability to landslides is Lau Gumba Village with an area of $2.64 \mathrm{Ha}$.

\section{Landslide Characteristics in the Research Area}

There are 2 (two) types of landslides found, namely translational type and rockfall type. The type of translational landslide is the most common type of landslide found in the study area. This type of landslide is a type of landslide movement in the form of displacement of rock material from a high place to a lower place through a slip plane in the form of a basin. The composition of rock and clay material will be saturated during the rainy season. This causes the binding force (cohesive) of the soil to weaken so that the shear force of the soil is getting stronger. In addition, land use factors and vegetation damage also affect the high risk of landslides.

This type of rockfall landslide is only found in Doulu Village with a fairly steep hilly area. Rock slope avalanches usually occur due to an misalignment between rock bonds during the slope formation process or also known as a Discontinuity Pattern. This misalignment can affect the value of the shear strength of the slope-forming material. Several factors triggering the occurrence of this type of landslide include the weathering process of rocks, the interaction of water with the slopes, and vibrations caused by earthquakes.

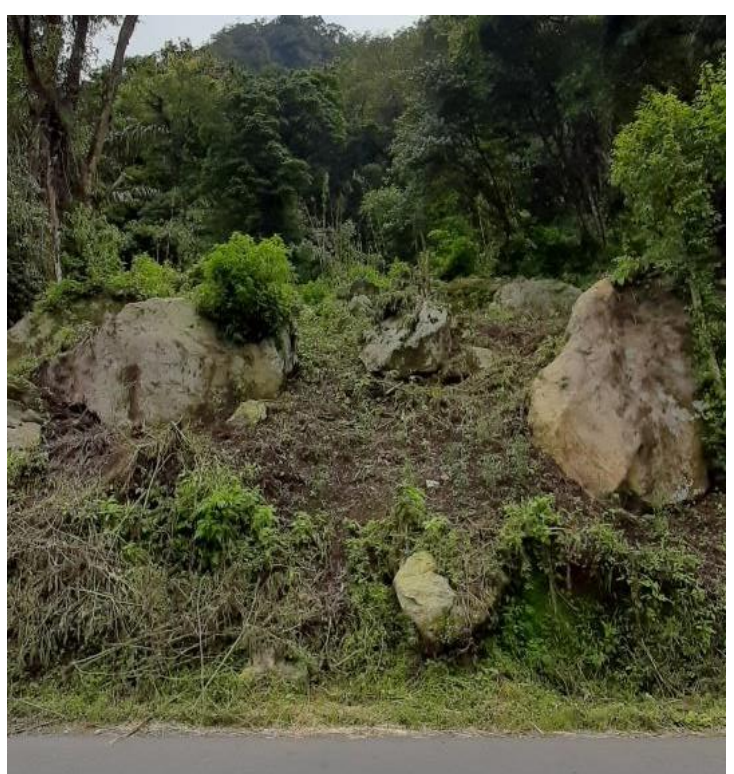

(a)

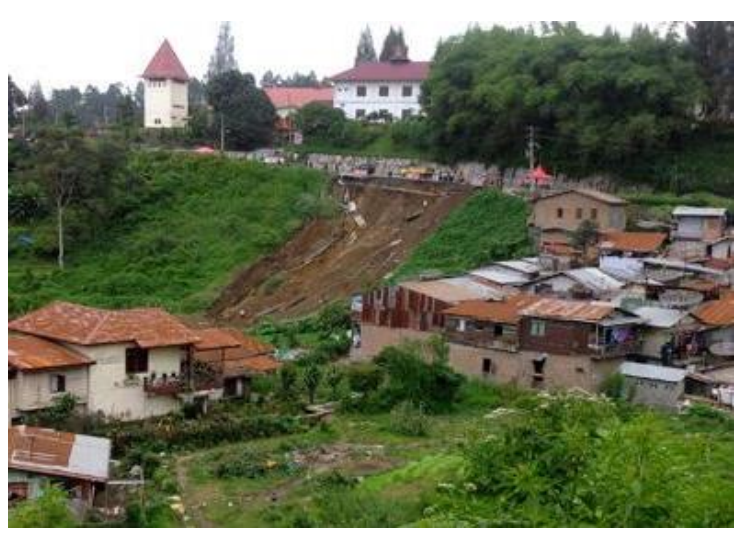

(b)

Figure 5.8 Types of landslides (a) Rockfall in Doulu Village and (b) translation in Tambak Lau Mulgap I Village 


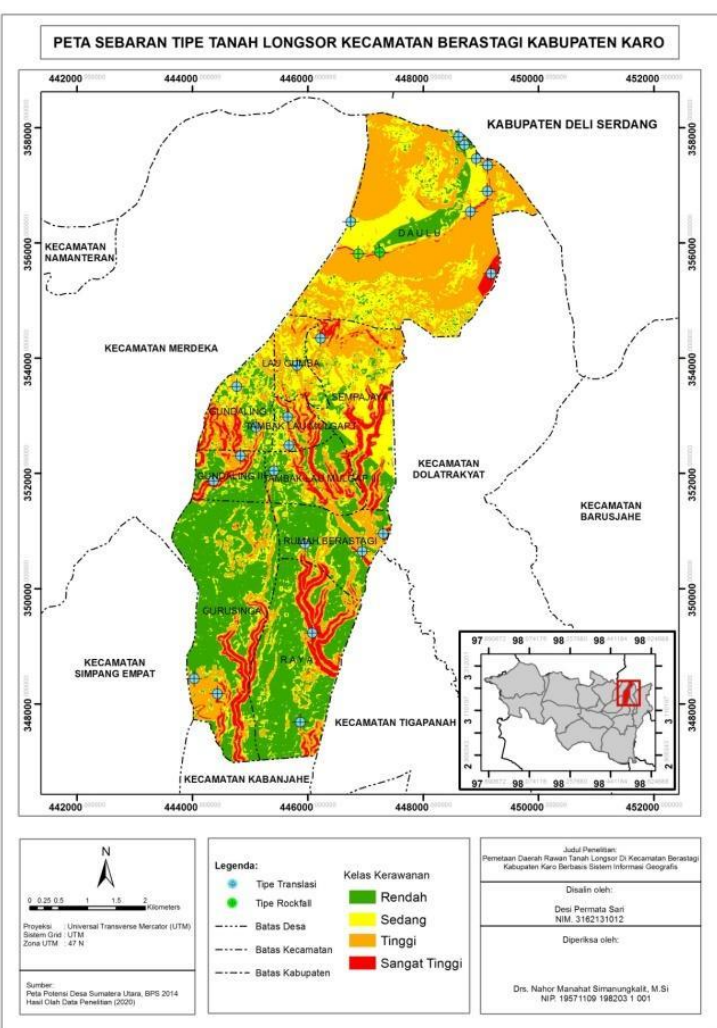

Figure 8. Distribution Map of Landslide Prone Areas Based on Village/Kelurahan

Administrative Areas and Landslide Types in Subdistricts Berastagi Karo Regency

\section{CONCLUSION}

Based on the results and discussions that have been described, the conclusions of this study are the results of the study indicate that there are 4 (four) levels/classes of landslide susceptibility in Berastagi District, Karo Regency, namely the low level of vulnerability level 1,036.76 hectares (33.16 $\%)$, the medium level of vulnerability area is $772.02 \mathrm{Ha}(24.69 \%)$, the high level of vulnerability is $1,055.53 \mathrm{Ha}(33.76 \%)$, and the very high level of vulnerability is $262.13 \mathrm{Ha}$ (8.38\%).

The low landslide susceptibility level is dominated by Guru Singa Village (10.83\%), Raya Village (8.66 \%), and Rumah Berastagi Village (3.72\%). The medium and high landslide susceptibility levels were dominated by Sempajaya Village at $4.51 \%$ and $3.68 \%$. The very high level of vulnerability to landslides is dominated by Doulu Village, which is $17.40 \%$. Meanwhile, the level of vulnerability to landslides in the other 5 (five) villages varies. Thus, $33.16 \%$ of the Berastagi District area is still safe from landslides, while the remaining $66.83 \%$ have varying levels of vulnerability. There are 2 (two) types of landslides in Berastagi District, namely translational landslides and rockfalls. Doulu Village is the village with the most landslide cases found.

Based on the conclusions of the results and discussion of the research, some suggestions that can be put forward by researchers are people need to strengthen disaster mitigation actions before landslides occur so that they can reduce the risk due to landslides. Among the landslide disaster mitigation actions that need to be considered are the application of soil conservation techniques on agricultural land, selection of plant types that are in accordance with the physical conditions of landslide-prone areas, engineering of slope cutting techniques, improving drainage systems, and socializing landslide disaster mitigation to be more massive to all residents of Berastagi District. More complete historical data of landslide events is needed for further research using landslide prediction modeling with different methods.

\section{ACKNOWLEDGEMENT}

Author of this paper would like to thank those who have helped and supported this research work, especially the Berastagi Subdistrict Head and Village Head who took the time to help. This study was financially supported by LPPM State University of Medan, our thanks also go to the chairman of the LPPM State University of Medan and the officers who contributed to facilitating research interests. Authors also would like to thank those who have helped and supported this research work, especially colleagues and lecturers who guide to complete the research, as well as to others who cannot be fully mentioned.

\section{REFERENCES}

Anonymous. (2006). Introduction to Ground Movement. Retrieved February 15, 2020, from http://esdm.go.id/

Geological Agency. (2017). Land movement. Bandung: Center for Volcanology and Geological

Hazard Mitigation, National Disaster Management Agency. (2016). Indonesian Disaster Risk. Jakarta: BNPB

BPS Berastagi District. (2019). Berastagi District in Figures 2019. Berastagi: Central Bureau of Statistics, BerastagiDistrict

Damanik, MRS and Restu. (2012). North Sumatra Flood and Landslide Risk Level Mapping Based on Geographic Information System. Journal of Geography, 4 (1)

Minister of Agriculture Number 837/KPTS/UM. (1980). Regarding Criteria and 
Procedures for Determining Protection Forests

Nohani, I. (2019). Landslide Susceptibility Mapping Using Different GIS - Based Bivariate Models. Waters, 11 (1402).

Nurwihastuti, DW, Astuti, AJD, \& Yuniastuti, Eni. (2016). Landslide Hazard Analysis Based on Geomorphological Approach in Karo Highland, North Sumatra Province, Indonesia. ICGE

Stevano Aversa, et al (2016). Landslides and Engineered Slopes - Experience, Theory and Practice. London: CLC Press

Drafting Team. (2015). Final Report of Bantek for Compilation of RPJIM for Human Settlements Sector of Karo Regency 2015-2019. Retrieved February 19, 2020, from http://sippa.ciptakarya.pu.go.id

RI (Republic of Indonesia). (2007). Law No. 24 of 2007 concerning Disaster Management. State Gazette of the Republic of Indonesia Year 2007, No. 66. State Secretariat. Jakarta 